\title{
Nuclear Radiation Detection Materials-2011
}




\section{MATERIALS RESEARCh SOCIETY \\ SYMPOSIUM PROCEEDINGS VOLUME 1341 \\ Nuclear Radiation Detection \\ Materials-2011}

Symposium held April 25-29, 2011, San Francisco, California, U.S.A.

\section{EDITORS}

\section{Michael Fiederle}

Albert-Ludwigs-Universitaet Freiburg

Freiburg, Germany

\section{Arnold Burger}

Fisk University

Nashville, Tennessee, U.S.A

\section{Larry Franks}

Special Technologies Laboratory

Santa Barbara, California, U.S.A.

\section{Kelvin Lynn}

Washington State University

Pullman, Washington, U.S.A.

\section{Dale L. Perry}

Lawrence Berkeley National Laboratory

Berkeley, California, U.S.A.

\section{Kazuhito Yasuda}

Nagoya Institute of Technology

Nagoya, Japan

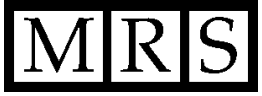

Materials Research Society

Warrendale, Pennsylvania

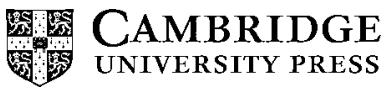


CAMBRIDGE UNIVERSITY PRESS

Cambridge, New York, Melbourne, Madrid, Cape Town,

Singapore, São Paulo, Delhi, Tokyo, Mexico City

Cambridge University Press

32 Avenue of the Americas, New York, NY 10013-2473, USA

www.cambridge.org

Information on this title: www.cambridge.org/9781605113180

Materials Research Society

506 Keystone Drive, Warrendale, PA 15086, USA

http://www.mrs.org

(c) Materials Research Society 2012

This publication is in copyright. Subject to statutory exception and to the provisions of relevant collective licensing agreements, no reproduction of any part may take place without the written permission of Cambridge University Press.

This book has been registered with Copyright Clearance Center, Inc. For further information please contact the Copyright Clearance Center, Salem, Massachusetts.

First published 2012

\section{CODEN: MRSPDH}

ISBN: 978-1-60511-318-0 Hardback

Cambridge University Press has no responsibility for the persistence or accuracy of URLs for external or third-party Internet Web sites referred to in this publication and does not guarantee that any content on such Web sites is, or will remain, accurate or appropriate. 


\section{CONTENTS}

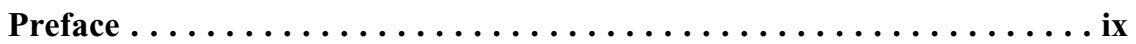

Materials Research Society Symposium Proceedings........... xi SCINTILLATORS

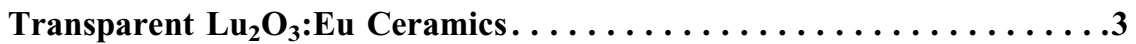

Zachary M. Seeley, Joshua D. Kuntz,

Nerine J. Cherepy, and Stephen A. Payne

Nuclear Radiation Detection Scintillators Based

on $\mathrm{ZnSe}(\mathrm{Te})$ Crystals...........................9

Volodymyr D. Ryzhikov

Nonlinear Quenching Rates in $\mathrm{SrI}_{2}$ and CsI Scintillator Hosts ......15 Joel Q. Grim, Qi Li, K.B. Ucer, R.T. Williams,

A. Burger, P. Bhattacharya, E. Tupitsyn,

G.A. Bizarri, and W.W. Moses

Bridgman Growth of $\operatorname{SrI}_{2} \ldots \ldots \ldots \ldots \ldots \ldots \ldots \ldots \ldots \ldots \ldots \ldots$

Leonard Alaribe, Christian Disch, Alex Fauler,

Ralf Engels, Egbert Keller, Angelica Cecilia,

Tomy dos Santos Rolo, and Michael Fiederle

\section{CdZnTe}

\section{* Growth of Detector-grade CZT by Traveling Heater Method}

(THM): An Advancement. .........................29

U.N. Roy, S. Weiler, J. Stein, M. Groza,

A. Burger, A.E. Bolotnikov, G.S. Camarda,

A. Hossain, G. Yang, and R.B. James

Low Temperature Crystal Growth and Characterization of $\mathrm{Cd}_{0.9} \mathbf{Z n}_{0.1}$ Te for Radiation Detection Applications ...........39

Ramesh M. Krishna, Timothy C. Hayes,

Peter G. Muzykov, and Krishna C. Mandal

*Invited Paper 
Improvement of CdMnTe Detector Performance

by MnTe Purification .........................45

K.H. Kim, A.E. Bolotnikov, G.S. Camarda,

R. Tappero, A. Hossain, Y. Cui,

G. Yang, R. Gul, and R.B. James

* Characterization of Pd Impurities and Finite-Sized Defects

in Detector Grade CdZnTe ......................51

M.C. Duff, J.P. Bradley, Z.R. Dai, N. Teslich,

A. Burger, M. Groza, and V. Buliga

Effects of Dislocations and Sub-grain Boundaries

on X-ray Response Maps of CdZnTe Radiation Detectors. .........61

A. Hossain, A.E. Bolotnikov, G.S. Camarda,

Y. Cui, R. Gul, K. Kim, B. Raghothamachar,

G. Yang, and R.B. James

Study of Structural Defects in CdZnTe Crystals by High

Resolution Electron Microscopy....................67

A. Hossain, A.E. Bolotnikov, G.S. Camarda,

Y. Cui, R. Gul, K-H. Kim, K. Kisslinger, D. Su,

G. Yang, L.H. Zhang, and R.B. James

\section{MODELLING AND CALCULATIONS}

Performance Evaluation of Neutron Detectors Incorporating

Intrinsic Gd Using a GEANT4 Modeling Approach . . . . . . . . . 75

Abigail A. Bickley, Christopher Young,

Benjamin Thomas, John W. McClory,

Peter A. Dowben, and James C. Petrosky

Material Parameter Basis for Major and Minor Trends

in Nonproportionality of Scintillators.

Qi Li, Joel Q. Grim, R.T. Williams,

G.A. Bizarri, and W.W. Moses

Dimensionally Reduced Heavy Atom Semiconductors

as Candidate Materials for $\gamma$-ray Detection:

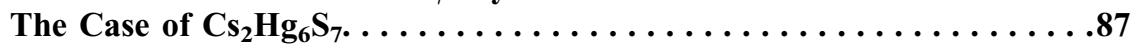

Ioannis Androulakis, Hao Li, Christos Malliakas,

John A. Peters, Zhifu Liu, Bruce W. Wessels,

Jung-Hwan Song, Hosub Jin, Arthur J. Freeman,

and Mercouri G. Kanatzidis

*Invited Paper 


\section{*zochralski Growth of Indium Iodide and Other Wide}

Bandgap Semiconductor Compounds.................95

I. Nicoara, D. Nicoara, C. Bertorello, G.A. Slack,

A.G. Ostrogorsky, M. Groza, and A. Burger

Dysprosium-containing Nanocrystals for Thermal

Neutron Detection.

Antonio C. Rivera, Natasha N. Glazener,

Nathaniel C. Cook, Nathan J. Withers,

John B. Plumley, Brian A. Akins, Ken Carpenter,

Gennady A. Smolyakov, Robert D. Busch, and Marek Osiński

* Semiconductor Detectors Fabricated From TIBr Crystals

Keitaro Hitomi, Tsutomu Tada, Seong-Yun Kim,

Yan Wu, Hiromichi Yamazaki, Tadayoshi Shoji,

and Keizo Ishii

UV Emitting Single Crystalline Film Scintillators Grown

by LPE Method: Current Status and Perspective ..............119

Yuriy Zorenko, Vitaliy Gorbenko, Volodymyr Savchyn,

Taras Voznyak, Miroslaw Batentschuk,

Albrecht Winnacker, Qi Xia, and Christoph Brabec

\section{Bismuth-loaded Polymer Scintillators for Gamma}

Ray Spectroscopy .............................125

Benjmain L. Rupert, Nerine J. Cherepy,

Benjamin W. Sturm, Robert D. Sanner,

Zurong Dai, and Stephen A. Payne

Alkali Metal Chalcogenides for Radiation Detection

J.A. Peters, Zhifu Liu, B.W. Wessels, I. Androulakis,

C.P. Sebastian, Hao Li, and M.G. Kanatzidis

ZnCdSeTe Semiconductor Compounds: Preparation

and Properties

Vello Valdna, Maarja Grossberg, Jaan Hiie,

Urve Kallavus, Valdek Mikli, Taavi Raadik,

Rainer Traksmaa, and Mart Viljus

*Invited Paper 
Comparative Study of $\mathrm{HgI}_{2}, \mathrm{PbI}_{2}$ and $\mathrm{TIBr}$ Films

Aimed for Ionizing Radiation Detection in Medical Imaging. . . . . . . .145

Marcelo Mulato, José F. Condeles, Julio C. Ugucioni,

Ademar M. Caldeira-Filho, and Natalia Destefano

Photoemission and Cathodoluminescence of Doped Lithium

Tetraborate Crystals Being Developed for Neutron Detection . . . . . . .151

Christina L. Dugan, Robert L. Hengehold,

Stephen R. McHale, Yaroslav Losovyj,

John W. McClory, and James C. Petrosky

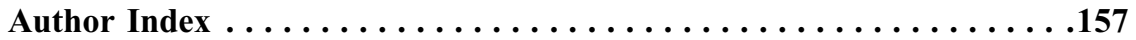

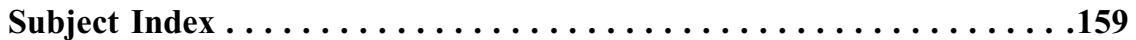




\section{PREFACE}

Symposium U, "Nuclear Radiation Detection Materials," held April 26-28 at the 2011 MRS Spring Meeting in San Francisco, California, provides the latest results and discussion of nuclear radiation detection materials. The symposium gave an overview of the crystal growth of the radiation detector materials, the characterization and the technology issues.

There is a strong need for new materials and methods for a variety of radiation detection applications. The types of detector materials include semiconductors and scintillators, which are represented by a variety of new scintillator materials, novel semiconductors, and traditional detection materials. This symposium was the continuation of the symposium from 2009 and it shows a rapidly growing field with several important improvements for the development of future radiation detectors.

Michael Fiederle

Dale L. Perry

Arnold Burger

Larry Franks

Kazuhito Yasuda

Kelvin Lynn

November 2011 


\section{Materials Research Society Symposium Proceedings}

Volume 1321 - Amorphous and Polycrystalline Thin-Film Silicon Science and Technology-2011, B. Yan, S. Higashi, C.C. Tsai, Q. Wang, H. Gleskova, 2011, ISBN 978-1-60511-298-5

Volume 1322 - Third-Generation and Emerging Solar-Cell Technologies, Y. Lu, J.M. Merrill, M.T. Lusk, S. Bailey, A. Franceschetti, 2011, ISBN 978-1-60511-299-2

Volume 1323 - Advanced Materials Processing for Scalable Solar-Cell Manufacturing, L. Tsakalakos, H. Ji, B. Ren, 2011, ISBN 978-1-60511-300-5

Volume 1324 - Compound Semiconductors for Energy Applications and Environmental Sustainability2011, F. Shahedipour-Sandvik, L.D. Bell, K. Jones, B. Simpkins, D. Schaadt, M. Contreras, 2011, ISBN 978-1-60511-301-2

Volume 1325 - Energy Harvesting-Recent Advances in Materials, Devices and Applications, R. Venkatasubramanian, H. Liang, H. Radousky, J. Poon, 2011, ISBN 978-1-60511-302-9

Volume 1326E - Renewable Fuels and Nanotechnology, H. Idriss, 2011, ISBN 978-1-60511-303-6

Volume 1327 - Complex Oxide Materials for Emerging Energy Technologies, J.D. Perkins, A. Ohtomo, H.N. Lee, G. Herranz, 2011, ISBN 978-1-60511-304-3

Volume 1328E - Electrochromic Materials and Devices, M. Bendikov, D. Gillaspie, T. Richardson, 2011, ISBN 978-1-60511-305-0

Volume 1329E - Nanoscale Heat Transfer-Thermoelectrics, Thermophotovoltaics and Emerging Thermal Devices, K. Nielsch, S.F. Fischer, B.J.H. Stadler, T. Kamins, 2011, ISBN 978-1-60511-306-7

Volume 1330E - Protons in Solids, V. Peterson, 2011, ISBN 978-1-60511-307-4

Volume 1331E - Frontiers of Solid-State Ionics, K. Kita, 2011, ISBN 978-1-60511-308-1

Volume 1332E - Interfacial Phenomena and In-Situ Techniques for Electrochemical Energy Storage and Conversion, H. Li, 2011, ISBN 978-1-60511-309-8

Volume 1333E - Nanostructured Materials for Energy Storage, J. Lemmon, 2011, ISBN 978-1-60511-310-4

Volume 1334E - Recent Developments in Materials for Hydrogen Storage and Carbon-Capture Technologies, R. Zidan, 2011, ISBN 978-1-60511-311-1

Volume 1335 - Materials, Processes, and Reliability for Advanced Interconnects for Micro- and Nanoelectronics-2011, M. Baklanov, G. Dubois, C. Dussarrat, T. Kokubo, S. Ogawa, 2011, ISBN 978-1-60511-312-8

Volume 1336E - Interface Engineering for Post-CMOS Emerging Channel Materials, Y. Kamata, 2011, ISBN 978-1-60511-313-5

Volume 1337 - New Functional Materials and Emerging Device Architectures for Nonvolatile Memories, D. Wouters, O. Auciello, P. Dimitrakis, Y. Fujisaki, E. Tokumitsu, 2011, ISBN 978-1-60511-314-2

Volume 1338E - Phase-Change Materials for Memory and Reconfigurable Electronics Applications, B.-K. Cheong, P. Fons, B.J. Kooi, B.-S. Lee, R. Zhao, 2011, ISBN 978-1-60511-315-9

Volume 1339E - Plasma-Assisted Materials Processing and Synthesis, J.L. Endrino, A. Anders, J. Andersson, D. Horwat, M. Vinnichenko, 2011, ISBN 978-1-60511-316-6

Volume 1340E - High-Speed and Large-Area Printing of Micro/Nanostructures and Devices, T. Sekitani, 2011, ISBN 978-1-60511-317-3

Volume 1341 - Nuclear Radiation Detection Materials-2011, A. Burger, M. Fiederle, L. Franks, K. Lynn, D.L. Perry, K. Yasuda, 2011, ISBN 978-1-60511-318-0

Volume 1342 - Rare-Earth Doping of Advanced Materials for Photonic Applications-2011, V. Dierolf, Y. Fujiwara, T. Gregorkiewicz, W.M. Jadwisienczak, 2011, ISBN 978-1-60511-319-7

Volume 1343E - Recent Progress in Metamaterials and Plasmonics, G.J. Brown, J. Pendry, D. Smith, Y. Lu, N.X. Fang, 2011, ISBN 978-1-60511-320-3

Volume 1344 - Functional Two-Dimensional Layered Materials-From Graphene to Topological Insulators, A.A. Balandin, A. Geim, J. Huang, D. Li, 2011, ISBN 978-1-60511-321-0

Volume 1345E - Nanoscale Electromechanics of Inorganic, Macromolecular and Biological Systems, J. Li, S.V. Kalinin, M.-F. Yu, P.S. Weiss, 2011, ISBN 978-1-60511-322-7

Volume 1346 - Micro- and Nanofluidic Systems for Materials Synthesis, Device Assembly and Bioanalysis-2011, R. Fan, J. Fu, J. Qin, A. Radenovic, 2011, ISBN 978-1-60511-323-4

Volume 1347E - Nanoscale Heat Transport-From Fundamentals to Devices, A. McGaughey, M. Su, S. Putnam, J. Shiomi, 2011, ISBN 978-1-60511-324-1 


\section{Materials Research Society Symposium Proceedings}

Volume 1348E - Hybrid Interfaces and Devices, D.S. Ginley, N.R. Armstrong, G. Frey, R.T. Collins, 2011, ISBN 978-1-60511-325-8

Volume 1349E - Quantitative Characterization of Nanostructured Materials, A. Kirkland, 2011, ISBN 978-1-60511-326-5

Volume 1350E - Semiconductor Nanowires-From Fundamentals to Applications, V. Schmidt, L.J. Lauhon, T. Fukui, G.T. Wang, M. Björk, 2011, ISBN 978-1-60511-327-2

Volume 1351 - Surfaces and Nanomaterials for Catalysis through In-Situ or Ex-Situ Studies, F. Tao, M. Salmeron, J.A. Rodriguez, J. Hu, 2011, ISBN 978-1-60511-328-9

Volume 1352 - Titanium Dioxide Nanomaterials, X. Chen, M. Graetzel, C. Li, P.D. Cozzoli, 2011, ISBN 978-1-60511-329-6

Volume 1353E - The Business of Nanotechnology III, L. Merhari, M. Biberger, D. Cruikshank, M. Theelen, 2011, ISBN 978-1-60511-330-2

Volume 1354 - Ion Beams - New Applications from Mesoscale to Nanoscale, J. Baglin, D. ILA, G. Marletta, A. Öztarhan, 2011, ISBN 978-1-60511-331-9

Volume 1355E - Biological Hybrid Materials for Life Sciences, L. Stanciu, S. Andreescu, T. Noguer, B. Liu, 2011, ISBN 978-1-60511-332-6

Volume 1356E - Microbial Life on Surfaces-Biofilm-Material Interactions, N. Abu-Lail, W. Goodson, B.H. Lower, M. Fornalik, R. Lins, 2011, ISBN 978-1-60511-333-3

Volume 1357E - Biomimetic Engineering of Micro- and Nanoparticles, D. Discher, 2011, ISBN 978-1-60511-334-0

Volume 1358E - Organic Bioelectronics and Photonics for Sensing and Regulation, L. Torsi, 2011, ISBN 978-1-60511-335-7

Volume 1359 - Electronic Organic and Inorganic Hybrid Nanomaterials-Synthesis, Device Physics and Their Applications, Z.-L. Zhou, C. Sanchez, M. Popall, J. Pei, 2011, ISBN 978-1-60511-336-4

Volume 1360 - Synthesis and Processing of Organic and Polymeric Materials for Semiconductor Applications, A.B. Padmaperuma, J. Li, C.-C. Wu, J.-B. Xu, N.S. Radu, 2011, ISBN 978-1-60511-337-1

Volume 1361E - Engineering Polymers for Stem-Cell-Fate Regulation and Regenerative Medicine, S. Heilshorn, J.C. Liu, S. Lyu, W. Shen, 2011, ISBN 978-1-60511-338-8

Volume 1362 - Carbon Functional Interfaces, J.A. Garrido, K. Haenen, D. Ho, K.P. Loh, 2011, ISBN 978-1-60511-339-5

Volume 1363 - Fundamental Science of Defects and Microstructure in Advanced Materials for Energy, B.P. Uberuaga, A. El-Azab, G.M. Stocks, 2011, ISBN 978-1-60511-340-1

Volume 1364E - Forum on Materials Education and Evaluation-K-12, Undergraduate, Graduate and Informal, B.M. Olds, D. Steinberg, A. Risbud, 2011, ISBN 978-1-60511-341-8

Volume 1365 - Laser-Material Interactions at Micro/Nanoscales, Y. Lu, C.B. Arnold, C.P. Grigoropoulos, M. Stuke, S.M. Yalisove, 2011, ISBN 978-1-60511-342-5

Volume 1366E - Crystalline Nanoporous Framework Materials-Applications and Technological Feasibility, M.D. Allendorf, K. McCoy, A.A. Talin, S. Kaskel, 2011, ISBN 978-1-60511-343-2

Volume 1367E - Future Directions in High-Temperature Superconductivity-New Materials and Applications, C. Cantoni, A. Ballarino, K. Matsumoto, V. Solovyov, H. Wang, 2011, ISBN 978-1-60511-344-9

Volume 1368 - Multiferroic, Ferroelectric, and Functional Materials, Interfaces and Heterostructures, P. Paruch, E. Tsymbal, M. Rzchowski, T. Tybell, 2011, ISBN 978-1-60511-345-6

Volume 1369E - Computational Studies of Phase Stability and Microstructure Evolution, Z.-K. Liu, 2011, ISBN 978-1-60511-346-3

Volume 1370 - Computational Semiconductor Materials Science, L. Liu, S.-H. Wei, A. Rubio, H. Guo, 2011, ISBN 978-1-60511-347-0

Prior Materials Research Society Symposium Proceedings available by contacting Materials Research Society 